\title{
MARKETING
}

Received:

29 November, 2019

1st Revision:

29 December, 2019

Accepted:

30 December, 2019

UDC: 339.1

DOI https://doi.org/10.26661/2522-1566/2019-4/10-05

\section{DIGITAL MARKETING STRATEGY IN PROMOTING PRODUCT}

Imelda Debby Christina

London School of Public Relations

Jakarta, Indonesia

ORCID: 0000-0003-2300-7048

\author{
Fenni \\ London School of Public Relations \\ Jakarta, Indonesia \\ ORCID: 0000-0003-1163-2591
}

\author{
Devia Roselina \\ London School of Public Relations \\ Jakarta, Indonesia \\ ORCID: 0000-0002-9701-696X
}

*Corresponding author email: imeldebby@gmail.com

Abstract. A rapid internet development and its function has become one of the most important technologies in the world since it is very influential for human life. Considering this, one of the paid television companies makes an integrated marketing communication using internet as a tool for promoting its product. This study aims to know the role and strategy of various digital marketing channels, including website, search engine marketing (SEM), online PR, display advertising, email marketing and social media marketing in promoting product. The methodology is descriptive qualitative using interview and participant observation. The data were collected through documents and literature which related to digital marketing. This study found that digital marketing strategy has important role in promoting product. The whole digital marketing strategy, either in its planning, implementation, or evaluation, has its own uniqueness. It showed that digital marketing strategy has been run well within the company.

Keywords: digital marketing, integrated marketing communication, promotion, marketing communication strategy.

JEL Classification: M31, M37, M39.

\section{INTRODUCTION}

Technology has rapid development and continuous improvement which cannot be separated with the aspect of human's life. Technology has strong relation with internet as the most useful technology in the world. Based on the Indonesian Internet Service Provider Associations data, internet user keeps increasing year by year. As in 2014, the internet user had reached 88 million people and increased for $51.8 \%$ or 132.7 million people in 2016 (Widiartanto, 2016). This showed that most of Indonesian has already known about internet and the user will continue to increase in future.

Technology also affects people fulfilling their desire in getting entertainment, such as in television. Television is becoming a choice when people are getting bored or tired of their daily routines. This lead to the appearance of paid or subscription television as a tempting business. It is proved on the development of subscription television in Indonesia which already had various kinds of subscription television companies, such as Nexmedia, Indovision, UseeTV (Indihome), BigTV, K-Vision, First Media, MyRepublic, DensTV, Transvision, TopasTV, TopTV, Okevision, Skynindo, and so on, since 90s until now. 
Christina, I. D., Fenni and Roselina, D. (2019). "Digital marketing strategy in promoting product", Management and entrepreneurship: trends of development, 4 (10), pp. 58-66. Available at: https://doi.org/10.26661/2522-1566/20194/10-05

The competition between subscription televisions in Indonesia is very fierce. Some companies are survived until now but some are not. Even if the market enthusiast on subscription television is a lot but the amount of subscription television companies is also varies. They are offering their own strength and benefit to customers due to compete with their competitors. This intense competition makes them show their product's ability and strength and try to create a new strategy to make public choose their product by doing an integrated marketing communication strategy. Realizing that, a digital era is a suitable era to start focusing on enhancing marketing communication strategy through digital marketing or usually called as internet marketing. Internet marketing uses internet as a business tool in which a company can give special service and user can get his needs.Internet is not only functioned as searching and spreading information machine but more and wider than that. The power and diversity in digital marketing will keep on developing following the creativity and technology advance in future.

Seeing through the effectiveness and efficiency aspect, internet facilitates people to search information easily. Meanwhile, for company, internet facilitates in operational thing or uses as company marketing technique development. The uniqueness and the differentiation in other communication strategy within digital marketing are rated to become a right strategy to promote any kind of products. Therefore, this study aims to know about the digital marketing strategy in promoting product, including website, search engine marketing (SEM), online PR, display advertising, email marketing and social media marketing in promoting product.

\section{LITERATURE REVIEW}

\section{a) Communication strategy}

Pearce and Robinson (2008) define strategy as a group of decision and action that produce formula and plan designed to reach organization and company targets. Roland stated that the communication strategy is an activity or campaign which informational and persuasive in building understanding and support on an idea, thought, or structured service. The purpose of communication strategy according to Pace and Faules (2010) are;

- Secure understanding: to make sure the messages are delivered

- Establish acceptance: to keep building the delivered messages in a good way

- Move action: to motivate the next action

b) Integrated marketing communication

The American Association of Advertising Agency or known as the 4As claimed that the definition of integrated marketing communication is a marketing communication planning concept that aware with additional value from comprehensive plan. It evaluates the strategic role of various communication disciplines such as common advertising, direct response, sales promotion and public relation. Also, it combines some disciplines to give maximum clarity, consistency, and communication influence (Belch and Belch, 2015). Integrated marketing communication is a strategy which consists of various activities to deliver consistent message to public due to create long term relationship and product value. Moreover, an exact strategy which runs through integrated marketing communication will produce profit for company.

c) Promotional mix

Integrated marketing communication refers to the marketing communication tool. The basic tool used within integrated marketing communication is called as promotional mix, which in traditional concept it consists of some elements such as, advertising, sales promotion, public relation and personal selling. However, in modern concept, the element is added with direct marketing and digital marketing (Belch and Belch, 2015).

d) Digital marketing

Digital marketing nowadays holds important role in the development of integrated marketing communication and often used in modern era. According to Chaffey and Chadwick (2012), digital 
marketing can be defined as a tool for reaching marketing target through digital technology application which encompasses desktop, cellular phone, tablet, and other digital platform. Digital marketing is a modern communication which uses internet and digital technology and has relationship with traditional communication to achieve the goal. Therefore, in order to create a good integrated message, digital marketing should be followed with promotional mix to make it more optimal. Zahaydefines digital marketing as a digital technology used to facilitate the marketing process with final purpose to create customers' involvement and interaction (Zahay, 2015). Some media channel of digital marketing should be optimized due to reach a beneficiary result can be seen as below;

\section{Website}

Dan Morley in his article entitled "The 6 Fundamentals of digital Marketing 2016" claimed that website is a final result from all the things done within social media, search engine and online advertising to attract potential customer. Website is a place in which potential customer looks for something or decides to buy for something. Kotler and Armstrong, (2012) stated that website is a first step in doing online marketing. Website can be optimal if it owned a good hosting along with effective link. The effective link can be rated whether it presents the company and product or it can be remembered easily by people. Furthermore, it needs to see the content within the website since it can attract visitor to visit the website continuously.

\section{2. $\quad$ Search engine marketing}

Besides website,Chaffey and Chadwick (2012) claimed that there is another digital marketing channel which needs to be optimized due to support the digital marketing activity. Search engine marketing or SEM is a message placement in search engine to push user visit the website. It has function to optimize the search engine such as Google due to show the recommended website through keywords.

3. Online PR

In integrated marketing communication strategy, public relation has role to enhance brand message credibility and influence leader opinion or trendsetter. While online PR is public relation who does all the things above via online. Chaffey and Chadwick (2012) said that online PR in digital marketing means maximizing the name of company brand or in other word, letting the public know about the product information through website, social media or third party blog. Online PR also responds to negative news and does public relation through social media or blog.

\section{Display advertising}

Display advertising or known as display ads is the use of advertising in online media such as banner advertising either in static or dynamic to enhance brand awareness. Through display ads, internet user is pushed to click on the ads which then lead to the company website which has more complete information on the ads (Chaffey and Chadwick, 2012). Display ads can be used to create awareness that involve people into the direct marketing object. Display ads have various kinds and sizes such as leader's boards, rectangles, side panels, skyscrapers or verticals, also the form of display ads is static, animated or ads with fast display (Belch and Belch, 2015).

\section{5. $\quad$ E-mail marketing}

According to Chaffey and Chadwick, e-mail marketing is usually applied in outside communication from company to customer to push the buying demand or branding. E-mail marketing is often used to customer within the mail list (Chaffey and Chadwick, 2012). The use of e-mail as a promotion media can move internet user with the content inside the e-mail. The e-mail can be filled with promotion offering which then lead the user to the website for more information

\section{6. $\quad$ Social media marketing}

Social media marketing is an activity to monitoring and facilitates customer's interaction and participation in website to push positive involvement with the company and brand. Social media marketing is an important category of digital marketing which includes communication to customer through social network, blog or forum (Chaffey and Chadwick, 2012). Social media is a tool that 
Christina, I. D., Fenni and Roselina, D. (2019). "Digital marketing strategy in promoting product", Management and entrepreneurship: trends of development, 4 (10), pp. 58-66. Available at: https://doi.org/10.26661/2522-1566/20194/10-05

facilitates the communication between individuals or groups to be able to interact and exchange information on a product. Through social media, a company can delivers message to target audience and make a viral marketing or campaign in social media. Hence it could increase the interest of other social media user to follow on the campaign.

\section{METHODOLOGY}

The methodology uses in this study is qualitative using descriptive approach to explain on the digital marketing strategy used by PT.X as one of the subscription televisions in Indonesia. This study report on the result with systematic, factual, and accurate description on facts related to digital marketing strategy. This study uses study case to learn intensively on background problem of condition and position that is happening and the environment interaction within. This study observes in a very detail way on digital marketing strategy done by PT. X to promote its product optimally. The subject is digital marketing division of PT.X. The technique on data collection is done using primary and secondary data. The primary data is consisted of semi-structured interview with 3 internal interviewee related with digital marketing strategy. While the secondary data is obtained through documents, report, and various literature studies along with research article on digital marketing. The data is analyses using reduction, display and verification technique. The data are validated by triangulation source. Triangulation source is a digital marketing practitioner who had experience on digital marketing for 5 years long or more.

\section{RESULT AND DISCUSSION}

The result showed that PT. X uses various kind of digital marketing channels to promote its television subscription program to public. The digital marketing channels are consisting of website, search engine marketing, online PR, display advertising, e-mail marketing and social media marketing which describe as below;

1. Website

Kotler and Armstrong (2012) stated that website is the early phase in doing online marketing. Similar to informant's opinion who said that website is the first step to start digital marketing. Website is made with the name of brand as the link address in order to facilitate user to mention and remember the brand. It also facilitate user to search on search engine to look for the brand website. Some available features in company website are filled with top program, special events, and package. It is also filled with menu options such as channel, package, promotion, subscription and about us until menu for registering to the subscription program. These features make website fulfill the needs of customer and customer candidate to find out on product. The completeness of information, start from available channels, package price, available promo and the feature to subscribe help customer candidate easy to know about the brand. Then, after the candidate is clicked on the product offered, the candidate can directly subscribe on television channel through website. This will influence on the enhancement of product sales amount. For customer, website feature also made to make customer feel comfortable by proving the whole information in a website. From the website feature called Top Program is filled with the synopsis of best program that is airing or will be airing soon. All features are made to make customer visit the website regularly.

In an article entitled, "Digital Marketing and Social Media: Why Bother?" Tiago and Verissimo (2014) said that website can be a useful tool for market in creating brand power and get competitive profit. PT. X is not only creating complete and detail information on its product but also provides subscription feature within the website. Thus, it can be a marketing channel. The evaluation process done by PT. X toward the website is can be seen from the produced website traffic. The total conversion or sales can be seen through this website. However, based on the internal company data, PT. X has not yet reached its target on website traffic. But it does not 
happen in website conversion. PT. X has reached 1100 website conversion from 800 conversions per month. Traffic and conversion are also help by the other digital marketing channel. Therefore the evaluation which done by PT. X is rated as good since it showed the other types of digital marketing channel that support the website traffic and it can be optimized more in future.

2. Search engine marketing

One of the digital marketing channels that has biggest role in contributing website traffic is search engine marketing. It has function to optimize the spread of information and promotion in internet. The search engine marketing in PT.X uses persuasive sentence along with promotional description to attract internet user to click the ads in search engine. The search engine marketing planning is started by defining the keywords to be input in search engine machine. PT. X has used its brand name as a keyword and the other keyword is something that related with television subscription such as television subscription, paid television, television with no satellite, and other. According to Zahay (2015) search engine marketing is divided into two types, namely non-paid through search engine optimization (SEO) and paid through pay per click. PT. X also uses both of the SEM types. In SEO, PT. X optimize the blog within website and social media to increase the keyword relevance that often used by internet user while searching on television subscription. Meanwhile, in pay per click, PT. X uses Google AdWords which formed using persuasive sentence to optimize the product promotion strategy.

In doing evaluation on SEM, PT. X uses real time evaluation in which every implementation will be evaluated together with the effectiveness on keyword performance to help enhance the website traffic. The result showed that SEM can contribute $80 \%$ traffic of the whole channels. Thus, SEM is the biggest channel that helps website traffic. PT. X also exceed the target for $70 \%$ in SEM which mean that the strategy of SEM has run well and succeed in supporting digital marketing goal through website. In accordance with triangulation source that real time evaluation and testing trial and error are evaluation that should be done in doing the digital marketing strategy due to optimize the estimation budget.

\section{Online PR}

PT. X optimizes online PR as one of the digital marketing channels to support the promotion of its product. If according to Chaffey and Chadwick online PR means maximizing the brand names or product in website or social media, blog and third party media (Chaffey and Chadwick, 2012), PT. X do online PR in social media and blog only. Moreover, PT. X runs offline PR such as media relations, press conference or press release to support positive news of its brand in news portal.PT. $\mathrm{X}$ also do media monitoring on positive and negative news on internet. If there is negative news, as what happen on one of the digital marketing portal, then the customer care will handle the complaint as soon as possible.

PT. X do online PR based on Chaffey's and Chadwick's opinion that is responding to negative news in internet (Chaffey and Chadwick, 2012). If the target on complaint service is 70\%, PT. X has been handling $80 \%$ of complaint in very good way. By doing media monitoring regularly, it will be able to handle the negative news faster. Thus it will minimize the negative news in internet on the product and the company.

4. Display advertising

Besides online PR, another important digital marketing channel used to promote product is display ads. Display ads have also big contribution in promoting product. Ivanova (2012) claimed that there is positive point for integrated marketing communication if it uses internet for full media application support, in which internet provides picture and font until voice and video in one unity of internet advertising. Display ad is one of the digital marketing channels that adapt on it. Display ad is delivering message or information with interesting visualization designed by PT. X. In display ad planning through google display network or news portal website, PT. X promotes its product by giving information on shows in its channel and makes it as an interesting visualization promotion. PT. X also makes design visualization by using promotional price as the main design seen within 
Christina, I. D., Fenni and Roselina, D. (2019). "Digital marketing strategy in promoting product", Management and entrepreneurship: trends of development, 4 (10), pp. 58-66. Available at: https://doi.org/10.26661/2522-1566/20194/10-05

the display ad. Therefore, it will make internet user pushed to click on the ad which then directed to the company website that provide detail information about the product.

PT. X uses bright color for its display ads supported with interesting content image such as soccer player to promote Sports Platinum package or cartoon to promote Kids package. PT. X also put the price as the noticeable picture within the display ad to strengthen the promotion. It encourages people who see the ads, interest to subscribe on the product. The effectiveness of display ads can be seen through how much people aware and click on the ads. If the intensity produced through display ads is big then it means that the image that carried is right and interesting. Display ad has target on $20 \%$ traffic and PT. X has exceeded the target for $30 \%$ traffic. This can be the standard to do other strategy in the future.

5. E-mail marketing

In e-mail marketing, PT. X uses it as interlace with customer. As Chaffey and Chadwick said that e-mail marketing is the most used channel to inform customer about the product. By using mail list, PT. X can directly send e-mail to its customers. Mail list in PT. X which owned by portfolio team can be adjusted based on the customer's target segmentation. In running e-mail marketing, PT. $\mathrm{X}$ has already had planning by defining on what kind of information that will be sent through email. Then it defines the target segmentation of e-mail receiver that suit the information. For example, information on the opening of all channels can be sent to customer who has subscribed for a year. The portfolio team will sort the customer based on their subscription duration, thus the email which sent to them will be match with their subscription duration. After that, PT.X evaluates the open rate from e-mail marketing to know the amount of e-mail received by customer. The target of e-mail marketing is the open rate reach $20 \%$ but PT.X has reached $40 \%$ in open rate. This open rate result will be the standard to fix and enhance the content creativity on e-mail to make the open rate increase optimally in the future.

6. $\quad$ Social media marketing

Social media marketing is also become the digital marketing channel to promote product. In doing social media marketing, PT. X uses three kinds of platform, namely Facebook, Twitter and Instagram. These platforms have similar content but different posting time. The number of post is 4 times a dayin each social media, except on Twitter. It happens since twitter should update continuously in order to make the timeline read by follower. If there is an event or promotion, the number of post will be multiply to increase the promotion. Social media has role in spreading various kind of information and promote the product. Through three kinds of posting that are \#Guide, \#Show and \#Info, PT. X has formed consistent information. \#Guide as a content that give information on product details such as how to solve troubleshooting, information on customer care phone number, the program schedule, and the tutorial on how to make the payment. \#Show is interesting information filled with program showed in channels while \#Info is the news info nowadays. All of theese information becomes the guidelines for digital marketing team to make content in each day. These can be the standard to reach target engagement in the form of likes for about 8 likes for each post.

A journal entitled, “The Internet's Impact on Integrated Marketing Communication” claimed that one of the benefit in using internet as marketing communication strategy is can build an interactive relationship with customer (Ivanova, 2012). As in social media, the customer can communicate with customer care to complaint or ask for product information. Hartiningsih in her article entitled, "Internet Advertising sebagai Media KomunikasiPemasaranInteraktif" stated that one of the internet advertising function is to build customer relationship management (Hartiningsih, 2013). PT. X has been build customer relationship management through social media by handling customer's complaint until help customer solve the problem. Therefore, customer will be satisfied and spread positive issue on brand to their friend or their followers.

PT.X has been given interesting and advantage information to its customer through digital marketing strategy via social media. By giving information on product promotion will make people interest with to buy the product. An article entitled, "The Effects of Social Media Marketing on 
Online Consumer Behavior" explained that the involvement of customer means focus on the customer commitment not on the transaction (Vinerean, Cetina, Dumitrescu and Tichindelan, 2013). Hence, PT. X makes promotion on soft selling and prioritizes on the content to build interest to customer and customer candidate to the product. Arifah (2015) stated that there are some strategies that can be implemented within social media. One of the strategies is by holding a giveaway or quiz. PT. $X$ has been done one of the strategies to run social media marketing in promoting the product. The quiz is made as attractive as possible to enhance customer's trust toward the brand. It is proved that quiz makes the number of follower increased. However, there is still deficiency on target engagement. Most of the posts do not reach the target engagement.

\section{CONCLUSION}

Based on the analysis on digital marketing communication strategy in PT.X, it can be concluded that PT. X has run its strategy in a right stages, including planning, implantation, and evaluation to reach the company's target and goal. PT. X uses various kind of digital marketing media channel to get beneficial result to promote the product optimally, such as website, search engine marketing, online PR, display advertising, e-mail marketing, and social media marketing. Therefore, the strategy on digital marketing in PT.X is declared as running well since it has succeeded in reaching the target goal. Public can get information on the product very well through internet. This information enhances their knowledge on product and its specialty which makes them interest and do the subscription. Digital marketing is not only giving information to the customer but also to customer candidate. This will support the purpose of integrated marketing communication to produce and increase the product sales. Digital marketing has uniqueness in its ability to get public attention faster. This makes digital marketing an exact strategy in running integrated marketing communication in present and in future.

For further research the same topic with different objects or programs and methods are suggested to consider. Quantitative methodology is recommended to be seen as a method that shows how significant is the impact of digital marketing activity done by the company on public desire to buy a product or service.

\section{REFERENCES}

Arifah, F. N. (2015). “Analisis Sosial Media sebagai Strategi Marketing dalam Bisnis Online”, TRANSFORMASI Jurnal Informasi \& Pengembangan Iptek, 11(2), pp. 143-149. Available at: https://docplayer.info/48986086-Analisis-sosial-media-sebagai-strategi-marketing-dalambisnis-online.html (accessed 3 November 2019), (in Indonesian).

Belch, G. E. and Belch, M. A. (2015). Advertising and promotion: an integrated marketing communications perspective. New York: McGraw-Hill.

Chaffey, D. and Chadwick, F. E. (2012). Digital Marketing: Strategy, Implementation and Practice. London: Pearson.

Hariningsih, E. (2013). "Internet Advertising sebagai Media Komunikasi Pemasaran Interaktif", JBMA, Vol. I, No. 2, pp. 12-16.Available at: http://www.amaypk.ac.id/download/jurnal/Internet_Advertising_Sebagai_Media_Komunikasi _Pemasaran_Interaktif.pdf (accessed 5 November 2019), (in Indonesian).

Ivanova, A.E. (2012). "The Internet's Impact on Integrated Marketing Communication", Procedia Economics and Finance, 3, pp.536-542. Available at: http://dx.doi.org/10.1016/s22125671(12)00192-x (accessed 26 October 2019)

Kotler, P. and Armstrong, G. (2012). Prinsip-prinsip pemasaran (Edisi 13). Jakarta: Erlangga, (in Indonesian). 
Christina, I. D., Fenni and Roselina, D. (2019). "Digital marketing strategy in promoting product", Management and entrepreneurship: trends of development, 4 (10), pp. 58-66. Available at: https://doi.org/10.26661/2522-1566/20194/10-05

Pace, W. and Faules, D. F. (2010). Komunikasi Organisasi: Strategi Meningkatkan Kinerja Perusahaan. Bandung: Remaja Rosdakarya, (in Indonesian).

Pearce, J. A. and Robinson, R. B. J. (2008). Manajemen Strategis 10. Jakarta: Salemba Empat, (in Indonesian).

Tiago, M.T.P.M.B. and Veríssimo, J.M.C. (2014).” Digital marketing and social media: Why bother?" Business Horizons, 57(6), pp.703-708. Available at: http://dx.doi.org/10.1016/j.bushor.2014.07.002 (accessed 13 October 2019).

Vinerean, S. et al. (2013). "The Effects of Social Media Marketing on Online Consumer Behavior", International Journal of Business and Management, 8(14). Available at: http://dx.doi.org/10.5539/ijbm.v8n14p66 (accessed 14 October 2019).

Widiartanto, Y. H. (2016). Pengguna Internet di Indonesia Capai 132 Juta. Kompas.com. Available

https://tekno.kompas.com/read/2016/10/24/15064727/2016.pengguna.internet.di.indonesia.ca pai.132.juta (accessed 1 October 2019).

Zahay, D. (2015). Digital Marketing Management: A Handbook for the Current (or Future) CEO. New York: Business Expert Press.

\section{ЦИФРОВА МАРКЕТИНГОВА СТРАТЕГІЯ ДЛЯ ПРОСУВАННЯ ПРОДУКЦЇ̈}

\author{
Imelda Debby Christina \\ Лондонська школа \\ суспільних відносин \\ Джкакарта, Індонезія
}

\author{
Fenni \\ Лондонська школа \\ суспільних відносин \\ Джакарта, Індонезія
}

\author{
Devia Roselina \\ Лондонська школа \\ суспільних відносин \\ Дэсакарта, Індонезія
}

Швидкий розвиток Інтернету та його функції стали однією з найважливіших технологій у світі, оскільки це дуже впливає на життя людини. Враховуючи це, одна 3 платних телекомпаній здійснює інтегровану маркетингову комунікацію, використовуючи Інтернет як інструмент просування свого продукту. Це дослідження має на меті визначити роль та стратегію різних каналів цифрового маркетингу, включаючи веб-сайт, маркетинг пошукових систем (SEM), інтернет-PR, медіарекламу, електронний маркетинг та маркетинг соціальних медіа у просуванні товару. Методологія описує використання інтерв'ю та спостереження за учасниками. Дані були зібрані за допомогою документів та літератури, що стосуються цифрового маркетингу. Це дослідження показало, що стратегія цифрового маркетингу відіграє важливу роль у просуванні товару. Вся стратегія цифрового маркетингу, або в його плануванні, реалізації, або оцінці, має свою унікальність. Дослідження виявило, що стратегія цифрового маркетингу добре працює у компанії. Для подальшого дослідження пропонується розглянути ту саму тему 3 різними об'єктами чи програмами та методами. Кількісну методологію рекомендується розглядати як метод, який показує, наскільки суттєвим є вплив діяльності цифрового маркетингу, здійснюваний компанією на бажання громадськості придбати товар чи послугу.

Ключові слова: цифровий маркетинг, інтегрована маркетингова комунікація, просування, маркетингова комунікаційна стратегія 


\section{ЦИФРОВАЯ МАРКЕТИНГОВАЯ СТРАТЕГИЯ ДЛЯ ПРОДВИЖЕНИЯ ПРОДУКЦИИ}

Imelda Debby Christina

Лондонская школа

общественных отношений

Джсакарта, Индонезия

\author{
Fenni \\ Лондонская школа \\ общественных отношений \\ Джакарта, Индонезия
}

\author{
Devia Roselina \\ Лондонская школа \\ общественных отношений \\ Джскарта, Индонезия
}

Быстрое развитие интернета и его функции стали одной из самых важных технологий в мире, поскольку они очень важны для жизни человека. Учитывая это, одна из платных телевизионных компаний осуществляет интегрированную маркетинговую коммуникацию, используя Интернет как инструмент продвижения своего продукта. Это исследование направлено на то, чтобы узнать роль и стратегию различных каналов цифрового маркетинга, включая веб-сайт, маркетинг в поисковых системах (SEM), онлайн-PR, медийную рекламу, маркетинг по электронной почте и маркетинг в социальных сетях в продвижении продукта. Методология описывает использование интервью и наблюдение за участниками. Данные были собраны с помощью документов и литературы, связанных с цифровым маркетингом. Это исследование показало, что стратегия цифрового маркетинга играет важную роль в продвижении продукта. Вся стратегия цифрового маркетинга, будь то планирование, реализация или оценка, имеет свою уникальность. Это показало, что стратегия цифрового маркетинга хорошо работает внутри компании.

Ключевые слова: цифровой маркетинг, интегрированные маркетинговые коммуникации, продвижение, маркетинговые коммуникационные стратегии 